Santa Clara Law

Santa Clara Law Digital Commons

\title{
The Facebook Effect: Secondary Markets and Insider Trading in Today's Startup Environment
}

Stephen F. Diamond

Santa Clara University School of Law, sdiamond@scu.edu

Follow this and additional works at: https://digitalcommons.law.scu.edu/facpubs

Part of the Law Commons

\section{Automated Citation}

Stephen F. Diamond, The Facebook Effect: Secondary Markets and Insider Trading in Today's Startup Environment (2012),

Available at: https://digitalcommons.law.scu.edu/facpubs/192

This Article is brought to you for free and open access by the Faculty Scholarship at Santa Clara Law Digital Commons. It has been accepted for inclusion in Faculty Publications by an authorized administrator of Santa Clara Law Digital Commons. For more information, please contact sculawlibrarian@gmail.com. 


\section{The Facebook effect: secondary markets and insider trading in today's startup environment Stephen F. Diamond}

\section{INTRODUCTION}

The ubiquitous social networking company Facebook made headlines in the spring of 2011 when it fired a widely respected senior manager because he violated the firm's insider trading policy. ${ }^{1}$ The dismissal was controversial not only because it surprised Silicon Valley and led many there to rush to the executive's defense, but also because it opened up a new chapter in a long-running policy debate about the nature of insider trading. The debate revealed a good deal of confusion about the legality and significance of insider transactions. One leading technology sector blog even went so far as to quote unnamed sources in a post on the matter stating - inaccurately - that insider trading was legal as long as it took place in the shares of a private company. ${ }^{2}$

Beyond the issue of insider trading, however, the incident raised concerns about the emergence of new private capital markets such as SharesPost and SecondMarket, where prior to their initial public offerings (IPOs) the securities of high-flying companies such as Facebook, Yelp, Zynga, and Groupon could be bought and sold with relative ease without the need to make the kinds of disclosure required of publicly traded companies. The trades that the Facebook executive made were allegedly carried out on such a private trading platform.

If the numbers reported in the wake of these trades can be believed, valuations of some private companies can reach stratospheric levels. Based on a pre-IPO trade in Facebook stock made through its service, SharesPost valued the social networking company at nearly $\$ 103$ billion in 2012 , up from $\$ 17$ billion in the spring of $2010 .^{3}$ These kinds of numbers drive up the demand for shares in private companies. Because corporate insiders are one of the few sources of supply of such shares, skyrocketing valuations may tempt insiders to engage in trades with investors outside the company. The temptation to trade may be exacerbated when, as in the current economic crisis,

1 Miguel Helft, Facebook Fires Employee for Insider Trading, N.Y. Times Blogs (Bits) (Apr. 1, 2011, 3:40 PM, updated 4:53 PM), http://bits.blogs.nytimes.com/2011/04/01/facebookfires-employee-for-insider-trading/ (last visited Nov. 20, 2012).

2 Michael Arrington, Facebook Terminated Corporate Development Employee Over Insider Trading Scandal, TechCrunch (Mar. 31, 2011), http://techcrunch.com/2011/03/31/facebookterminated-corporate-development-employee-over-insider-trading-scandal/ (last visited Nov. 20, 2012).

${ }^{3}$ Brian Womack, Facebook Valued At $\$ 102.8$ Billion In Final Auction On SharesPost, Bloomberg, Mar. 30, 2012, http://www.bloomberg.com/news/2012-03-30/facebook-valued-at-1028-billion-in-final-sharespost-auction.html (last visited Nov. 20, 2012). 
startups have long delayed expected public offerings of their stock. ${ }^{4}$ Not all private trades by insiders are illegal, of course, but the Facebook incident highlights why it is important for lawyers engaged in representing startup companies or investors in such companies to consider carefully the impact of federal and state securities laws on insider transactions.

\section{BUSINESS LAWYERS ARE "SECURITIES LAWYERS"}

Many law students avoid taking securities law in law school, yet it becomes clear in practice that almost any lawyer advising a business will encounter securities law issues. Thus, it is helpful to recall that the Securities and Exchange Commission (SEC) paints with a broad brush the definition of who is or is not practicing securities law. Although the SEC imposes no registration requirement or other formal oversight of attorneys, Section 307 of the Sarbanes Oxley Act of $2002^{5}$ (SOX) mandated that the SEC establish "minimum standards of professional conduct for lawyers appearing and practicing before the Commission." ${ }^{6}$ The SEC implemented a final rule with respect to these standards in January 2003 . $^{7}$

In light of the broad approach long taken by the Commission to the phrase "appearing and practicing," which has its origins in the longstanding rules of practice on which the new rule 8 implementing this SOX provision is based, a lawyer who provides what seems to be the simplest form of advice to a new business entity may, in fact, be considered to be practicing securities law. The SOX provision, for example, includes the following as a form of "appearing and practicing" before the Commission:

(iv) Advising an issuer as to whether information or a statement, opinion, or other writing is required under the United States securities laws or the Commission's rules or regulations thereunder to be filed with or submitted to, or incorporated into any document that will be filed with or submitted to, the Commission. ${ }^{9}$

Even at the earliest stage of the incorporation of a business, decisions need to be made with respect to the basic capital structure of the new entity. How much and what classes of stock will be authorized and issued? On what terms and conditions will they be issued? At what price per share will they be valued? To whom will the securities be issued? And, of course, will it be necessary to register the issuance of these securities with the SEC or,

4 IPO Task Force, Rebuilding the IPO On-Ramp 6 (2011). ("The average age at IPO of companies going public between 1997 and 2001 was approximately five and a half years, compared with more than nine years for companies going public between 2006 and 2011.")

5 Sarbanes Oxley Act of 2002, 15 U.S.C. $\$ \$ 7201-7266$ (2002).

6 Id. $§ 7245$.

7 Standards of Professional Conduct for Attorneys Appearing and Practicing Before the Commission in the Representation of an Issuer, 17 C.F.R. $\S 205$ (2012). See also Standards of Professional Conduct for Attorneys, Securities Act Release No 33,8185, Exchange Act Release No 34,47276, 68 Fed. Reg. 6296 (Feb. 6, 2003).

$8 \quad 17$ C.F.R. $\S 205.2$ (a) (2012).

$9 \quad 17$ C.F.R. $\$ 205.2(\mathrm{a})(1)(\mathrm{iv})(2012)$. 
in the case of Silicon Valley startups, qualify them with the California Department of Corporations? Or is there an exemption from registration and qualification available? ${ }^{10}$ The last of these questions falls squarely under the Commission's definition because a lawyer representing a newly formed corporation must help the founders decide whether they need to make a filing with the SEC in connection with the issuance of the company's securities.

The potential penalties for violating state and federal securities laws are severe. Willful violations of the California securities law are punishable by a fine of up to $\$ 1$ million or imprisonment for up to one year, or both. ${ }^{11}$ Willful violations of the 1933 Act are punishable by a fine of up to $\$ 10,000$ or imprisonment for up to five years, or both. ${ }^{12}$ Although criminal convictions under these statutes are relatively rare, prosecutions for charges under insider trading laws are increasing in frequency. Most visibly, in 2011 hedge fund billionaire Raj Rajaratnam was convicted of 14 counts of conspiracy and securities fraud and sentenced to 11 years in federal prison in connection with a widespread insider trading operation that he masterminded. ${ }^{13}$ In 2012, Rajat Gupta, a former managing partner of McKinsey \& Co. and board member of Goldman Sachs, was also found guilty of passing inside information to Rajaratnam and faces the possibility of decades in prison. ${ }^{14}$ Thirteen other figures involved in the Rajaratnam scandal have each received, on average, a sentence of three years in prison. ${ }^{15}$

\section{III. "FOLLOW THE MONEY"}

The clearest way to understand the potential effect of the securities laws on a startup company is to track the creation, distribution, and resale of securities issued by the company. Numerous issues related to both securities and corporate law emerge in the startup company process, most of which are beyond the scope of this chapter. ${ }^{16}$ However, the process can be tracked to better understand the impact of both the insider trading laws and the issues triggered by the emergence of new trading platforms such as SharesPost and SecondMarket.

Once a startup company is incorporated, it typically issues shares of common stock to founders and early stage employees. Later, as the firm expands, it may issue preferred stock to angel investors or venture capitalists. The fundamental question that must

10 See generally Securities Act of 1933, as amended, 15 U.S.C. $\$ \S 77 a-77 a a(2012)$ (1933 Act); California Corporate Securities Law of 1968, Corp. C. $\$ \S 25000-25707$ (2012).

11 See Corp. C. $\S 25540$ (2012).

12 See 15 U.S.C. $\$ 77 x$ (2012).

13 Peter Lattman, Galleon Chief Sentenced to 11-Year Term in Insider Case, N. Y. Times, Oct. 30, 2011, http://dealbook.nytimes.com/2011/10/13/rajaratnam-is-sentenced-to-11-years/ (last visited Nov. 20, 2012).

14 Patricia Hurtado, et al., Rajat Gupta Convicted Of Insider Trading, Bloomberg, Jun. 16, 2012, http://www.bloomberg.com/news/2012-06-15/rajat-gupta-convicted-of-insider-trading-by-us-jury.html (last visited Nov. 20, 2012).

15 Lattman, supra note 13.

16 See generally California Continuing Education of the Bar, Financing and Protecting California Businesses (2006, updated Mar. 2012). 
be asked when a company contemplates an issuance of securities such as common or preferred stock is whether the issuance will require registration with the SEC or qualification by the California Department of Corporations. If registration and qualification are required the company will have to undertake the expensive and time-consuming preparation of an information package that must be reviewed and approved by regulators and then provided to potential investors.

The central principle animating the federal registration requirement is whether the individuals receiving or purchasing the securities can "fend for themselves," ${ }^{17}$ i.e., whether they have sufficient information and sophistication to decide whether the investment decision they are being asked by the issuer to make is a reasonable one. If they can fend for themselves, then the transaction in those securities will not be a public offering and thus will be exempt from registration. ${ }^{18}$ Because this standard can be challenging to meet, the SEC has, over the years, used its rule-making authority to establish safe harbors from registration that allow a transaction to proceed with certainty that registration is not required. If an issuer or seller of a security is not confident that the sale will be exempt or that it meets the strict requirements of a safe harbor, then the transaction must be registered with the SEC and likely also qualified by the California Department of Corporations.

The California securities law is a so-called "merit statute" that applies a "fair, just and equitable" standard to proposed offers or sales of securities in California. ${ }^{19}$ Just as federal law does, California law offers a set of exemptions from its qualification requirements. ${ }^{20}$ In some instances, federal law pre-empts the California requirement to qualify the offer and sale of securities under California law. ${ }^{21}$

The legal framework described above implements what one might call the "prime directive" of securities law, namely that the offer and sale of any security must be registered (with the SEC) and/or qualified (by the California Department of Corporations) or both, unless an applicable exemption is available. It should not come as a surprise that securities regulators take a very broad view of what constitutes a "security." Parsing out the elements of that definition is beyond the scope of this chapter, but almost any financial instrument issued by a startup to investors, such as preferred stock, common stock, or options to purchase either of those, will fall within that definition..$^{22}$

Because the registration and qualification process is costly, complex, and time consuming, federal and state regulators have established several safe harbors that make capital formation simpler and cheaper for issuers. Thus, in most instances, it is fairly straightforward for firms to issue securities to founders as well as early stage employees and investors without incurring the cost of registration and qualification..$^{23}$ As the company grows in size, it may wish to raise additional rounds of capital by engaging in similar private placements (i.e., sales of securities made without registration or qualification) with investors,

\footnotetext{
SEC v. Ralston Purina Co., 346 U.S. 119, 125 (1953).

See id.

See Corp. C. $\S 25140$ (a) (2012).

See Corp. C. $\S \S 25102,25102.1,25102.5,25103-25104$ (2012).

See 15 U.S.C. $\$ 77 \mathrm{r}(\mathrm{b})(2012)$

See 15 U.S.C. $\$ 77 b(a)(1)$ (2012); Corp. C. § 25019 (2012).

See, e.g., Rule 701, 17 C.F.R. § 230.701 (2012); Corp. C. § 25102(f) (2012).
} 
as well as to issue additional shares to employees or consultants. Each such issuance will require its own exemption or safe harbor.

Whether a company's securities are sold through a public offering or a private placement, the company is required in most cases to make available to potential purchasers a basic information package that helps level the playing field between the issuer and the purchaser. In a public offering (i.e., a securities offering that is registered with the SEC), the package will include a prospectus that is reviewed and commented on by the SEC staff itself before actual sales of securities can take place. In a private placement, the issuer may provide potential investors with direct access to business records (e.g., if the investors are senior officers of the issuer or early stage angel investors) or prepare an offering memorandum or private placement memorandum that summarizes key business and financial information. It is in the issuer's interest to provide enough information to enable investors to make a reasonable decision regarding whether to enter into the transaction. The issuer's motivation to disclose material information is reinforced by the fact that the anti-fraud rules apply to all securities transactions, including transactions exempt from registration. ${ }^{24}$

\section{THE SECONDARY MARKET FOR SECURITIES}

The initial issuance and sale of securities by a startup company represents the first stage in creating a market for a company's securities. Once the shares or other securities are in the hands of those initial purchasers, they can be resold to other investors, thus providing liquidity for the original purchaser. In this secondary "resale" market, of course, no cash is generated for the issuer, only for the seller. Nonetheless, the seller must still comply with federal and state securities laws - the "prime directive" still applies. ${ }^{25}$ Thus, unless an exemption is available, a seller must provide sufficient information to a potential purchaser to enable him or her to make a reasonable decision regarding whether to buy the securities offered. The purchaser normally must have the sophistication to analyze the information provided, thus meeting the "fend for themselves" standard discussed above.

Unless the seller has negotiated with the original issuer (e.g., in a registration rights agreement) to make the information available, the information requirement will be a difficult burden to meet. Moreover, even if an exemption from registration or qualification is available, the anti-fraud rules still apply.

There are readily available safe harbors that exempt most secondary sales of common stock in public corporations. ${ }^{26} \mathrm{~A}$ much greater challenge is presented to the shareholder of a private company such as a typical startup. Because very little information is available publicly about such a company, a shareholder may find his or her investment in the company "locked in," awaiting the registration of his or her shares through an IPO. The shareholder may have received sufficient information from the company to purchase

\footnotetext{
24 See 15 U.S.C. $\S 78 j(b)$ (2012); 17 C.F.R. $§ 240.10 b-5$ (2012). See also Preliminary Notes, 17 C.F.R. $\$ 230.701(2012)$.

25 See 15 U.S.C. $\S 77 d(1)-(2)$ (2012); Corp. C. $\$ 25130$ (2012).

26 See 15 U.S.C. $\S 77 d(1)$ (2012); Corp. C. $\S 25111$ (2012).
} 
the securities initially from the firm. When he or she wishes to resell the shares, however, there may not be sufficient current information available to enable a prospective purchaser to make a reasonable decision regarding whether to purchase the shares in the resale (secondary) transaction.

Although all private companies face this problem, it has been exacerbated by recent difficult macroeconomic conditions. Since the dot.com crash in 2000-01, the length of time required for a startup to reach the IPO stage has increased significantly. ${ }^{27}$ The volatile market conditions that emerged in the wake of the 2008 credit crisis have made the problem more severe. Although it was formerly possible for companies to conduct relatively small IPOs, that is no longer the case. For example, when Intel first went public in 1971 , it raised only $\$ 7.2$ million..$^{28}$ Today, however, a company must often be large enough to raise at least $\$ 100$ million for an investment bank to be willing to expend the effort needed for a successful transaction. ${ }^{29}$ In late 2011, there were more than 200 companies waiting to complete their IPOs because market volatility caused a number of prospective new public companies to withdraw from the registration process. ${ }^{30}$ In September 2011, for the first time in 29 months, no IPOs whatsoever were conducted. ${ }^{31}$ As a result, an unknown number of investors in private companies have been left holding shares in companies that they would likely wish to sell but cannot because there is inadequate information available for prospective purchasers.

In light of these rough waters, new ways of providing liquidity to investors in early stage companies have emerged. Trading platforms such as SharesPost and SecondMarket offer shareholders in private companies an opportunity to connect with willing purchasers of their shares. As SecondMarket stated on its website, "SecondMarket specializes in designing and implementing fully-customized liquidity programs for private companies. Through these liquidity programs, private company shareholders can sell stock to company-approved investors in a company-controlled process. ${ }^{.32}$ Approximately $\$ 4.6$ billion worth of securities of private companies traded hands in 2010, although most of those transactions were done between buyers and sellers directly without participation of the new trading platforms. ${ }^{33}$ For both sellers and buyers of securities on the new trading

\footnotetext{
27 IPO Task Force, supra note 4.

28 Bruce C.N. Greenwald, et al., Value Investing 111 (2004).

29 Sandy Robertson, Remarks at the Executive Forum on Market Issues and Opportunities for Private Companies (May 10, 2011).

30 Rebecca Lipman, IPO Drought: For the First Time in 29 Months, Not a Single IPO, Kapitall
} Wire, Oct. 7, 2011, http://wire.kapitall.com/investment-idea/ipo-drought-for-the-first-time-in-29months-not-a-single-ipo/ (last visited Nov. 20, 2012).

31 Id.

32 SecondMarket at https://www.secondmarket.com/private-company?t=fl (last visited Nov. $15,2011)$.

33 Jean Eaglesham, Guidance Is Sought on Private Trading of Closely Held Companies, Wall St. J., May 9, 2011, http://professional.wsj.com/article/SB100014240527487048105045763102620 93052504.html\#articleTabs\%3Darticle (last visited Nov. 20, 2012). So-called "tertiary trades"where an investor who bought from an individual who received shares in a distribution wishes to resell those shares to another third-party investor-reportedly only rarely take place on the new trading platforms. Moreover, issuers do not generally engage in initial capital-raising offerings on these platforms. The platforms are thus distinguishable from stock exchanges such as the NASDAQ and NYSE. 
sites, the rules applicable to secondary securities transactions represent a complex legal minefield. Those rules ensure that the liquidity provided by secondary securities markets does not come at the cost of the core investor protections found in the federal and state securities laws.

The supply of securities for the new secondary trading platforms comes from several sources, each of which is seeking liquidity in startups that have not yet accessed the public markets or found another exit opportunity such as an acquisition. These sources include current and former employees whose stock options have vested, consultants or other service providers who may have earned shares as part of their short-term contributions to a business, and, finally, current investors in the startup. These security holders own so-called "restricted securities," i.e., shares issued without registration. To resell the securities to third parties, the security holder must find either a new exemption or a safe harbor from registration with the SEC and qualification with the California Department of Corporations. ${ }^{34}$

The federal securities laws do not provide an explicit exemption for the resale of restricted securities. Instead, a doctrine has been crafted over time in a series of decisions by courts, the SEC, and market participants that allows for valid resales of restricted securities. This doctrine combined language found in one section of the $1933 \mathrm{Act}^{35}$ with definitional information found in another ${ }^{36}$ to form a new informal rule known as "Rule 4(1 1/2)." Later, the SEC issued Rules $144^{37}$ and $144 \mathrm{~A}^{38}$ that created "safe harbors" for resales, thus providing buyers and sellers greater certainty that such transactions comply with the securities laws.

Ensuring that a resale complies with the securities laws is important for all three concerned parties - the seller, the buyer, and the issuer. The seller wants to avoid the costly and time-consuming obligation to draft a prospectus, which of course would require the issuer's cooperation. A buyer wants to make sure that the transaction complies so that the buyer can look forward to a further resale later on. The issuer has an important residual concern: if a resale without registration is not handled properly, the SEC could find that the seller was, in fact, acting as a statutory "underwriter" facilitating the distribution of the securities. ${ }^{39}$ If so, the two-part sale - the initial placement of the securities by the issuer with the seller and the later attempted resale by the seller to the buyer-would be collapsed into one transaction in which the issuer, as well as the seller-underwriter, would have joint responsibility for providing full prospectus-like disclosure to the buyer.

To ensure that buyers and sellers do not run afoul of these rules, the websites of the new trading firms explain that they screen potential investors so that they qualify for securities law exemptions or safe harbors. ${ }^{40}$ Thus, potential purchasers of the stock of private companies must qualify as "accredited investors" in order to participate in auctions for their

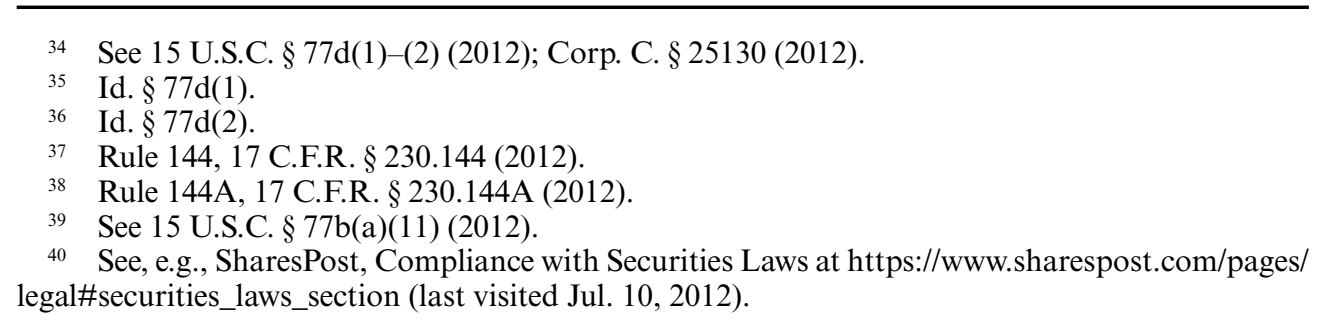


securities. Accredited investors are generally thought to be able to "fend for themselves" when it comes to deciding whether to purchase shares in a private transaction. The federal securities laws define an "accredited investor" to include a range of financial or business institutions as well as natural persons who meet certain qualifications. ${ }^{41}$

In addition, the secondary market sites state that they only allow sellers who have held their shares for more than one year (the holding period required by the Rule 144 safe harbor ${ }^{42}$ ) to resell their shares to other investors. The holding period helps to ensure that the original sale by the issuer (or its affiliate) to that seller was in fact an investment and not a distribution that would trigger a registration requirement. Finally, buyers on both SharesPost and SecondMarket must certify that they are qualified to participate in a private securities transaction.

\section{BACK TO INSIDER TRADING}

The growing concern about insider trading in the purchase and sale of the securities of private companies is founded on the laws governing the securities transactions discussed above. The primary policy motivation underpinning the regulation of trading by insiders (whether buying or selling) is the potential information asymmetry between the insider and his or her counter-party in the transaction. Inevitably, the insider will have more information about the fundamentals of a business than an outsider. Federal and state securities laws are intended, in part, to "level the playing field" among buyers and sellers by mandating disclosure of material information about a security as well as prohibiting fraud in securities transactions. ${ }^{43}$

The strongest view of insider trading thus argues for an absolute "disclose or abstain" approach $^{44}$ to achieve what the Second Circuit called "relatively equal access" to material information among all market participants. ${ }^{45}$ As discussed below, this approach is now limited by the requirement that the insider be in breach of a fiduciary obligation when he or she trades or provides information to others who trade. Nonetheless, this approach remains perhaps the most useful starting point for anyone in possession of material nonpublic information about a company's security, particularly employees or other potential insiders. In other words, if one party is in possession of material nonpublic information it is important for that party to stop before trading and ask whether he or she has an obligation here to "disclose or abstain." If so, that party must either provide the potential counter-party with the same material information that the first party has about the issuer, or else abstain entirely from entering into the transaction.

It is perfectly permissible, of course, for insiders to buy or sell the securities of the company of which they are considered insiders if there is in fact a level playing field

\footnotetext{
$41 \quad$ See 17 C.F.R. $\S 230.501(\mathrm{a})(1)-(5)$ (2012).

42 See 17 C.F.R. $\$ 230.144$ (d)(1)(ii) (2012).

43 SEC, SEC Enforcement Actions-Insider Trading Cases (2012), http://www.sec.gov/spot light/insidertrading/cases.shtml (last visited Nov. 20, 2012) (insider trading "undermin[es] the level playing field that is fundamental to the integrity and fair functioning of the capital markets").

44 See U.S. v. O'Hagan, 521 U.S. 642, 661 (1997).

45 SEC v. Texas Gulf Sulphur, 401 F.2d 833, 848 (2d Cir. 1968), cert. denied, 394 U.S. 976 (1969).
} 
between the insider and the counter-party on the other side of the transaction. Even if there is not equal access to the same information, absent a fiduciary duty, an insider may also be able to trade. ${ }^{46}$ Thus, insider trading per se is not always illegal. But it does not matter if the company is public or private, as was suggested by some in the wake of the controversy over Facebook's dismissal of the executive who engaged in the purchase of Facebook shares on a secondary market platform. ${ }^{47}$ All securities transactions are subject to the insider trading laws and rules. More importantly, it will often be difficult for individual insiders - who are not typically securities lawyers - to determine when they are free to trade.

The prohibition on insider trading is based largely on the SEC's and the federal courts' interpretation of the Securities Exchange Act of 1934 (1934 Act) rather than on an explicit statutory ban on the practice. ${ }^{48}$ The 1934 Act was passed in the wake of the stock market crash of 1929 during a period when it was widely believed that those "in the know" had benefitted at the expense of the wider investing public through a variety of manipulative investment practices. A Congressional investigation was concerned about this issue, stating in an oft-cited passage:

Among the most vicious practices unearthed at the hearings . . was the flagrant betrayal of their fiduciary duties by directors and officers of corporations who used their positions of trust and the confidential information which came to them in such positions, to aid them in their market activities. Closely allied to this type of abuse was the unscrupulous employment of inside information by large stockholders. . . ${ }^{49}$

Thus, $\S 10(\mathrm{~b})$ of the $1934 \mathrm{Act}^{50}$ states:

It shall be unlawful for any person, directly or indirectly, by the use of any means or instrumentality of interstate commerce or of the mails, or of any facility of any national securities exchange-...

b. To use or employ, in connection with the purchase or sale of any security registered on a national securities exchange or any security not so registered . . ., any manipulative or deceptive device or contrivance in contravention of such rules and regulations as the Commission may prescribe as necessary or appropriate in the public interest or for the protection of investors.

The SEC followed the passage of the 1934 Act by promulgating Rule 10b-5 in 1942 . Rule 10b-5 makes it unlawful "in connection with the purchase or sale of any security". ${ }^{51}$

\footnotetext{
46 See, e.g., Dirks v. SEC, 463 U.S. 646 (1983).

47 Arrington supra n. 2.

48 The 1934 Act does contain one explicit prohibition on insider trading in $\S 16$ (b). See 15
} U.S.C. $\S 78 p(b)$ (2012). However, this is a limited remedy. In addition to directors and officers, only holders of more than 10 percent of the company's stock are subject to the $\S 16(\mathrm{~b})$ prohibition. There is no tipper-tippee liability (discussed below) in the statutory language. Section 16(b) requires persons covered to return to the company any profits on purchases and sales that take place within six months of each other-the so-called "short swing" trading window. The broadly worded prohibition forces many trades to unwind that are not affected by inside information and can miss many that are so affected.

49 S. Rep. No 1455 at 55 (1934).

$50 \quad 15$ U.S.C. $\S 78 j(b)(2012)$.

51 C.F.R. $\$ 240.10$ b-5 (2012). 
(a) To employ any device, scheme, or artifice to defraud,

(b) To make any untrue statement of a material fact or to omit to state a material fact necessary in order to make the statements made, in the light of the circumstances under which they were made, not misleading, or

(c) To engage in any act, practice, or course of business which operates or would operate as a fraud or deceit upon any person.

Today, the insider trading prohibition is grounded on a narrower basis than the "level playing field" approach. In most instances, only where the insider owes a fiduciary duty to a less well-informed counter-party with respect to the information about the securities that he or she intends to trade would a purchase or sale to that counter-party be prohibited by law. The courts recognized this duty before modern statutory securities law and it was set forth as early as the U.S. Supreme Court's 1909 opinion in Strong v. Repide. ${ }^{52}$ In that case, the Court held that even though a director may not be under a fiduciary duty to disclose to a shareholder his or her knowledge affecting the value of the shares, a disclosure obligation might exist in special cases. This declaration of a "special circumstances" test began the process of dissolving the prevailing older rule that corporate directors and officers were free to take advantage of their inside knowledge when dealing with corporate shareholders.

Over time, as both the SEC and the courts began to interpret $\S 10(\mathrm{~b})$ and Rule 10b-5, the "special circumstances" approach broadened into the "classical theory" of insider trading. This theory covers both "permanent insiders" and those who become "temporary insiders" due to their access to material nonpublic information. The latter can include underwriters, lawyers, accountants, and consultants. ${ }^{53}$ Neither type of insider can legally trade in the securities of the entity to which they owe a fiduciary obligation while material nonpublic information remains undisclosed to the wider market. As the Supreme Court stated in United States v. O'Hagan (citations omitted):

[T]rading on such information qualifies as a "deceptive device" under $\S 10(\mathrm{~b}), \ldots$ because "a relationship of trust and confidence [exists] between the shareholders of a corporation and those insiders who have obtained confidential information by reason of their position with that corporation.". . That relationship ... "gives rise to a duty to disclose [or to abstain from trading] because of the "necessity of preventing a corporate insider from . . tak[ing] unfair advantage of ... uninformed ... stockholders." 54

In theory, the prohibition applies not only to actual insiders but also to persons who have been tipped off by those insiders. This is known as "tipper-tippee liability." The extension of liability to tippers and tippees enabled securities regulators to close a potential loophole that might have allowed insiders to pass on information to a friendly third party to trade, thus avoiding direct liability. There are two elements that must be met to impose liability on the tipper: (1) he or she must have had a duty that was violated by the disclosure of insider information to the tippee; and (2) he or she must have received some form of personal benefit from the disclosure..$^{55}$ Tippee liability is predicated on the exist-

\footnotetext{
213 U.S. 419 (1909).

See U.S. v. O'Hagan, 521 U.S. 642, 652 (1997).

Id. at 651-652.

55 See Dirks v. SEC, 463 U.S. 646, 662 (1983); SEC v. Yun, 327 F.3d 1263, 1269 (11th Cir. 2003).
} 
ence of the tipper's duty as well as awareness by the tippee that the duty was breached..$^{56}$ The ongoing Galleon hedge fund scandal involves examples of both tipper and tippee liability and demonstrates the aggressive posture the SEC takes towards this form of insider trading.

In O'Hagan, the Court broadened the scope of those covered by the insider trading prohibition with an endorsement of the "misappropriation theory" of insider trading. In that case, a lawyer working at a law firm representing the acquirer of a target company bought securities in the target before the takeover announcement. The Court held that the lawyer violated $\S 10$ (b) and Rule 10b-5 "when he misappropriate[d] confidential information for securities trading purposes, in breach of a duty owed to the source of the information," namely his own law firm and its client, the acquiring firm. ${ }^{57}$ Thus, the misappropriation theory complements the classical theory of insider trading with a ban on trading by outsiders who trade on "confidential information that will affect the corporation's security price when revealed, but who owe no fiduciary or other duty to that corporation's shareholders." ${ }^{8}$

\section{INSIDER TRADING POLICIES}

Determining whether a duty of nondisclosure is present and providing the kind of information that truly levels the playing field can be difficult, particularly in the context of startup companies. As a consequence, a directive to "disclose or abstain" will result in an abstention from trading, absent exceptional circumstances. Only the startup firm itself can effectively make available to counter-parties the kind of information that would ensure that a sale or purchase does not run afoul of the prohibition on insider trading. It is therefore prudent for the company itself to set the terms under which its employees, consultants, and advisors can trade in its securities.

Some startup companies have established an insider trading policy (IT Policy) in order to minimize the potential for problems. ${ }^{59} \mathrm{In}$ fact, it was his violation of such a policy that triggered the dismissal of the Facebook employee discussed above. ${ }^{60}$ An IT Policy was previously thought necessary only for companies whose securities already trade or are about to begin trading on the public capital markets. With the emergence of significant opportunities for insiders to trade on secondary markets such as SharesPost and SecondMarket, however, it is now important for many startup companies to consider implementing such policies.

Prepared by outside securities counsel, an IT Policy should make clear to all company

6 See Dirks, 463 U.S. at 661.

57 U.S. v. O'Hagan, 521 U.S. at 652.

58 Id. at 653 (citation omitted).

59 Amy Miller, Startup Companies Get Stock Transfer Advice, The Recorder, May 8, 2012, http://www.law.com/jsp/cc/PubArticleCC.jsp?id=1336331727848 (last visited Nov. 20, 2012). ("Long before filing to go public, both Facebook and Zynga Inc. instituted insider trading policies prohibiting current employees from selling their shares in the companies on secondary markets, except during periods when the companies opened trading windows.")

60 Helft, supra note 1. 
employees that trading by insiders may in certain circumstances be illegal under federal securities laws and carry severe penalties, including the possibility of imprisonment. Employees are more likely to take notice of their responsibilities under federal law when they are reminded that $\S 32$ (a) of the Exchange Act ${ }^{61}$ authorizes a judge to impose up to a $\$ 5$ million fine and a 20 -year prison sentence on those convicted of a $\$ 10(\mathrm{~b})$ violation. ${ }^{62}$ Section 32(a) also allows for criminal prosecutions against the issuing company if it is held responsible as a controlling person with respect to the illegal trading activity of its employees. ${ }^{63}$ Congress further raised the stakes for illegal insider trading with the passage of the Insider Trading Sanctions Act of $1984,{ }^{64}$ which allows the SEC to secure treble damages against violators ${ }^{65}$ Finally, in 1988, Congress created a private right of action to allow those who traded contemporaneously with insiders to sue for damages. ${ }^{66}$

The IT Policy should establish a general principle that no employee should trade or cause someone else to trade the company's securities while in possession of material nonpublic information. The company may wish to condition the issuance of stock to employees on an agreement not to trade in those securities until an agreed-on exit, such as a public offering. Some companies have gone further, replacing traditional stock options with various forms of restricted stock units (RSUs) that cannot be sold and for which there is no secondary market. The recipients of RSUs do not receive actual stock in the issuing firm until a public offering is conducted. ${ }^{67}$

The IT Policy itself should help educate rank and file employees, who are very likely not to have any familiarity with securities law, by providing clear examples of what material information means. Material information includes anything that might be considered reasonably important to the counter-party when making a decision concerning whether to engage in the purchase or sale of a security. This could include financial information such as revenues, operating margins, or net income; risk factors such as potential environmental liabilities; and background information on key executives. A leading U.S. Supreme Court opinion defined materiality as including anything that could significantly alter the "total mix" of information available about a particular company. ${ }^{68}$ Given the vagueness of this formulation, an IT policy should err on the side of over-inclusiveness when it defines materiality. A good example of such a policy, although it was prepared for a public company, can be found on the website of the Practical Law Company ${ }^{69}$

$61 \quad 15$ U.S.C. $\S 78 \mathrm{ff}(\mathrm{a})(2012)$

$62 \quad 15$ U.S.C. $\$ 78 \mathrm{j}$ (b) (2012).

63 One of the benefits of implementing an IT Policy is not only that it can lead to fewer instances of illegal trading by insiders but also that it can lead to mitigated sentences for a company under the Federal Sentencing Guidelines and provide a defense for the company to the imposition of controlling person liability. See United States Sentencing Commission, 2011 Federal Sentencing Guidelines Manual (2011), http://www.ussc.gov/Guidelines/2011_Guidelines/Manual_HTML/ index.cfm (last visited Nov. 20, 2012).

64 Pub. L. No 98-376, 98 Stat. 1264 (1984).

65 See 15 U.S.C. $§ 78 \mathrm{u}-1(\mathrm{a})(2)-(3)(2012)$.

66 See Insider Trading and Securities Fraud Enforcement Act, 15 U.S.C. § 78u-1 (2012).

${ }_{67}$ See Zynga, Inc., SEC No-Action Letter, 2011 SEC No-Act. LEXIS 415 (Jun. 17, 2011).

68 See TSC Indus., Inc. v. Northway, Inc., 426 U.S. 438, 449 (1976).

${ }^{69}$ Alan J. Berkeley, Sample Corporate Policy on Insider Trading, at http://us.practicallaw. com/7-502-0160?q = insider\%20trading\%20policy (last visited Nov. 20, 2012). 


\section{CONCLUSION}

Although the founders of, and investors in, early stage companies may chafe at the restrictions that an IT Policy places on liquidity, it is important that their counsel remind them of the far more catastrophic risk of facing liability for insider trading. In the intensely competitive environment of the startup world, reputational capital is likely the most precious asset that a young company owns. To risk that capital for short-term financial gain at the expense of outsiders makes no sense. 